\title{
The Study on the Function of the Defamiliarization in The House of Cards
}

\author{
Xue Meng \\ Media Arts and Culture \\ Communication University of China \\ Beijing, China
}

\begin{abstract}
The teleplay The House of Cards by the American video website Netflix has gained the continuing discussion and attention. The big hit caused by The House of Cards gives rise to people's reflection on it. The reasons of its success are usually simply attributed to the big data. The writer of this article, based on the Viktor Shklovsky's theory defamiliarization and the Brechtian's theory of distancing effect, considers that The House of Cards has the deautomation in which differs from other ordinary teleplays and makes this one so popular. This article is going to analyze the factors that lead to its success by analyzing the defamiliarizaion of its content, the form of diffusion and the promotion and that the proper use of defamiliarization contributed to the success of The House of Cards.
\end{abstract}

Keywords-defamiliarization; the House of Cards; aesthetic distance

\section{INTRODUCTION}

The teleplay The House of Cards by the American video website Netflix has gained the continuing discussion and attention. The diffusion in the first quarter in 2013 has attracted a growth of three million audiences, and in April, Netflix claimed that there were twenty-nine million registered members, the first time to surpass the TV network Home Box Office. Additionally, The House of Cards has also become a hit teleplay in over 40 other countries besides America. Once online in Sohu, six millions times of play has been achieved in the first month. Apart from the popularity from the audience, this teleplay even obtained nine nominations in 2013 Emmy Awards, creating a great legend of an internet drama.

The big hit caused by The House of Cards gives rise to people's reflection. The reasons of its success are usually simply attributed to the brilliant story line, writers and directors and actors, or to big data. The writer of this article considers that The House of Cards has the de-automation which differs from other ordinary teleplays that makes this one so popular. This article is going to analyze the factors that lead to its success by analyzing the defamiliarization of its content, the form of diffusion and the promotion.

A vivid lesson is given to the producers of traditional teleplays and the newly-developing internet networks by the hit of The House of Cards. The subject, theme, and the way of promotion all have made people concentrated on this work.
Compared with the national teleplays which talk about small household affairs and make fun of those time-penetrations, The House of Cards makes the audience realize the significance of defamiliarization to the production and diffusion of teleplays. The article will study the technique of defamiliarization of The House of Cards by analyzing three aspects of its content, the way of diffusion and promotion.

\section{THE CONCEPT OF DEFAMILIARIZATION}

Defamiliarization is the artistic technique of presenting to audience common things in an unfamiliar or strange way, in order to enhance perception of the familiar. A central concept in the 20th century art and theory, ranging over movements including Dada postmodernism, epic theatre, and science fiction, it is also used as a tactic by recent movements such as culture jamming.

The term "defamiliarization" was first coined in 1917 by Viktor Shklovsky in his essay "Art as Device" (alternate translation: "Art as Technique") (Crawford, 1984:209). Shklovsky invented the term as a means to "distinguish poetic from practical language on the basis of the former's perceptibility" (Crawford, 1984:209). Essentially, Shklovsky states that poetic language is fundamentally different than the language that people use every day because it is more difficult to understand: "Poetic speech is framed speech. Prose is ordinary speech, economical, easy and proper. The goddess of prose is a goddess of the accurate facile type of 'direct' expression of a child"(Shklovsky, 1998:20). This difference is the key to the creation of art and the prevention of "over-automatization," which causes an individual to "function as though by formula" (Shklovsky, 1998:16). This distinction between artistic language and everyday language, for Shklovsky, applies to all artistic forms.

The purpose of art is to impart the sensations of things as they are perceived and not as they are known. "The technique of art is to make objects 'unfamiliar,' to make forms difficult to increase the difficulty and length of perception because the process of perception is an aesthetic end in itself and must be prolonged." (Shklovsky, 1998:16)

Thus, defamiliarization serves as a means to force individuals to recognize artistic language:

In studying poetic speech in its phonetic and lexical structure as well as in its characteristic distribution of words 
and in the characteristic thought structures compounded from the words, we find everywhere the artistic trademark, that is, we find material obviously created to remove the automatism of perception; the author's purpose is to create the vision which results from that de-automatized perception. A work is created "artistically" so that its perception is impeded and the greatest possible effect is produced through the slowness of the perception. (Shklovsky, 1998:19)

This technique is meant to be especially useful in distinguishing poetry from prose, for, as Aristotle said, "poetic language must appear strange and wonderful." (Shklovsky, 1998:19)

The teleplay The House of Cards differs from other teleplays. It has a different manifestation of content, diffusion, and promotion. It transforms a political teleplay into a unique one which is distinctive but also authentic, bringing the audience a different experience of aesthetic appreciation and gaining the popularity.

There is a similar theory of defamiliarization. That is the distancing effect, which is brought up by Brecht. The distancing effect, more commonly known (earlier) by John Willett's 1964 translation the alienation effect, or (more recently) as the estrangement effect, is a performing art concept coined by playwright Bertolt Brecht. Brecht first used the term in an essay on "Alienation Effects in Chinese Acting" published in 1936, in which he described it as "playing in such a way that the audience was hindered from simply identifying itself with the characters in the play. Acceptance or rejection of their actions and utterances was meant to take place on a conscious plane, instead of, as hitherto, in the audience's subconscious."

The distancing effect is achieved by the way the "artist never acts as if there were a fourth wall besides the three surrounding him [...] The audience can no longer have the illusion of being the unseen spectator at an event which is really taking place" (Willett, 1964:91). The use of directly addressing the audience is one way of disrupting stage illusion and generating the distancing effect. In performance, as the performer "observes himself," his objective is "to appear strange and even surprising to the audience. He achieves this by looking strangely at himself and his work."(Willett, 1964:92)

The House of Cards is different from the other TV series in three ways: the content, the mode and the promotion, thus making a political teleplay more interesting and bringing the audience with unique anesthetic experience, so it can be welcomed by the audience.

\section{The USE OF DeFAMILIARIZATION IN THE HOUSE OF CARDS}

\section{A. The Defamiliarization of Content}

"The content triumphs": a good content is the basis of a teleplay and the defamilarization is substantially a kind of differentiation which makes the ordinary subject to be deformed and varied to make the audience feel strange and fresh, leading to the favor and interest of the receiver. The defamiliarization of Viktor Shklovsky usually manifests itself in the poetic language, but the theory of defamiliarization there is used to analyze the subject, theme, character setting and the narrative perspective of The House of Cards.

1) The defamiliarization of the subject matter: The House of Cards is novel in the subject matter. Since The West Wing in 2006, there rarely are politics-subjected teleplays in the US. With the situation comedy like The Big Bang Theory and the fantasy story like Arrow, The Vampire Diaries, the release of The House of Cards as a series of political topics is a technique of defamiliarizaiton of the subject. In the comparison with Homeland which is also a political TV series, there is a huge difference between their topics. Varied from those traditional political TV series reflecting the positive subject of anti-terrorist and homelandstability maintenance, The House of Cards configures the subject as an anti-hero political struggle to embrace the opposite. The popularity gained in China owed to this kind of defamiliarization when the national teleplays are suffering from an innovation deficiency, and it surely has arisen audience' feeling of freshness and attention by breaking ordinary audience' thinking method.

2) The defamiliarization of character setting: Traditionally, the main characters in a political teleplay are president, ministers and they always carry the country and the people on mind even if they are faced with a threat or an emotional string. The biggest stain they could have is some scandals as President Butler in The West Wing. Or the protagonist is a villain and there shall be a role of justice to contend with, and the end is always accord with Hegel's theory of the eternal victory of justice. However, in The House of Cards, the binary opposition of the good and the evil is eliminated and the main characters are born to get benefit and everything that can be done when the right and power shall be obtained. What is more, there is no one that can be called a nice guy including the protagonist and everyone is lying or victimizing for their own good. This sort of defamiliarization of character setting will astonish and surprise the audience while it makes them feel the sense of anxiety and tension that make a difference from their daily life. That is how a different experience of beauty is produced.

For example, In Season One the protagonist Francis Underwood is the House Majority Whip in the United States Congress and his wife Claire is a good wife of a politician. Before the ninth episode, they seem like a great couple. They support and help each other. But in the ninth episode, the audiences find out that Claire betrays his husband for her own interests. And Francis loves his classmate but not Claire. Their marriage is full of interests other than love. They are different from the protagonist of other TV series.

3) The defamiliarization of narrative Perspective: Narrative perspective or narrative focalization is a specific perspective to observe and narrate the story content through the narrative language. Viewed from different perspectives, 
the same incidence may appear differently and may mean differently to different people.

Those who have a refined research into the narrative perspective are the critics of structuralism. They have researched into the forms of narrative perspective in many aspects.

Gerard Genette, a French critic of structuralism, divided narrative perspective into three forms:

In omniscient perspective or zero perspective, the narrator knows more than any character. He knows and feels everything and there is no need for him to explain all that he knows to different readers. The narration can transcend everything. History, present and future - all are within his vision. Anything happens in any place even the concurrent events are within his knowledge. Under the circumstance, readers can only passively learn the story and the narration. The biggest and most obvious advantage of this narrative perspective lies in the infinite vision, which is suitable for the expression of the topic featuring a large time and space extension, complex contradictions and numerous characters. The other advantage of omniscient perspective lies in that the narration is plain and clear-cut, so the readers feel it relaxing to read.

In the interior narrative perspective, the narrator knows equal amount of information to that of the character. The narrator depends on the feeling and consciousness of a character and conveys everything through his vision, auditory sense and feeling. Different from the omniscient perspective, the narrator can neither provide the information that the character does not know, nor can he narrate beyond the knowledge of the character. In the interior narrative perspective, the narrator plays two roles in the scenario of the story. He either talks about the things he has experienced or reports what he has seen or heard, the credibility and affinity of the words are higher than those of omniscient perspective. That is also the reason why modern novels like adopting the interior narrative perspective. Gerard Genette, a French critic of structuralism, named the narrative perspective as inner focus. The limited character perspective includes two types, namely protagonist perspective and witness perspective.

In the exterior narrative perspective, the narrator knows less than the character. It is the opposite of omniscient perspective, because the narrator does not know all the information narrated; worse still, he knows even less than the characters. In the exterior narrative perspective, the narrator is like a person remaining uninformed of the inside information. He only narrates the behavior and language of the characters superficially. He could not explain or suggest any hidden or unhidden information related to the characters. The most significant character and merit of the exterior narrative perspective lies in its dramatic and objective demonstration nature. The direct and vivid expressive force also endows the works with fascinating charm of art. Its lack of the inside information boasts two extra advantages. On the one hand, it can make the novel appear mysterious, full of suspense and thought-provoking. Due to that, it is often adopted by the detective novels. On the other hand, readers face many gaps and uncertainties in the novel, so they have to fill up a thinking cap while reading it. In this way, their expectation vision, participation awareness and recreation ability of aesthetics have been stimulated to the utmost.

The characteristics of a narrative perspective are decided by the narrative person. Traditional narrative works mainly adopt the perspective of the bystander, or the third person narrative perspective (omniscient perspective). The third person narration is to narrate from the stance of the bystander not related to the story. Since the narrator is usually the bystander, whose identity is not clear, the traditional characteristic of the narration is no limitation. The narrator is like an omniscient god, who could appear at different places at the same time. He knows the past, predicts the future and could enter in the bottom of any character's heart to dig his or her privacy. Due to the movable narration perspective, the narration can also be called unfocused narration. All in all, this type of narration gives the author full freedom, because there is no perspective limitation.

Narrative works in the recent years mostly adopt the first person narration. In the first person narrative works, the narrator is also a character in the story. In this way, the narrative perspective is transferred into the works, becoming an inner focus narrative. There are two characteristics for the narrative perspective: Firstly, since the narrator is also a character in the story, he can not only participate in the whole process of the event, but can also leave the fictional environment to describe and evaluate the situation for the readers. The dual identity makes the character different from the rest of the characters in the works, which is more transparent and easier to be understood. It is a limited perspective.

Another narrative perspective rare to see is the second person narration, in which the protagonist or a character appears in the story as "you." This is a narrative perspective rare to see, because the narrative perspective seems to force the reader to become a part of the story. Although the reader is virtual, it makes the readers in real life feel strange.

Apart from the above three narrative perspectives, there is a particular circumstance in which the narration takes place by changing the persons and the perspectives. In the traditional narrative works, the narrator cannot be changed. Some theorists believe that the perspective should remain constant. In fact, it is not necessary for the perspective to remain the same.

The narrative perspective in The House of Cards adopts the interior narrative perspective. It is a character's limited perspective. The narrator usually adopts the third person, but he also changes to the direct dialogue between the protagonist Francis and the audience. In the omniscient perspective, Francis is a character and the narrator. He knows no more than any character. He knows and feels everything and there is no need for him to explain all that he knows to different readers. The narration could transcend everything. History, present and future - all are within vision. Anything about him happens in any place even the concurrent events are within his knowledge. For example, In Season One the first episode, Francis goes to the New Year 
party. And as a narrator, he introduces the other people directly to the audience. He says: "President elected Garrett Walker. Do I like him? No. Do I believe in him? That is beside the point... After 22 years in congress, I can smell which way the wind is going." Then he introduces the Vice President, Linda Vasquez and himself in this way. He is different from other characters, he knows everything about himself. On the one hand, the omniscient perspective makes the narration clearer; on the other hand, the direct dialogue between Francis and the audience makes this image transparent and much more thrilling. In this way, the audience will be more looking forward to the plot development.

The narrative perspective of The House of Cards is quite special and the technique of alienation is employed. Francis the protagonist usually has a direct conversation with the audience after an affair happens and this kind of directness makes his inner side known by the audience, which will lead to a sudden lighten-up after what has happened and let the audience expect to see what will happen next. For example, at the beginning of the first season of this teleplay, a dog in front of Francis' house is hit and Francis holds the dog while telling the audience that there are only two kinds of pains: "one makes people stronger while the other one is useless because it only makes people suffer from it, and I have no patience to useless things." Then he chokes the life of the dog. By doing this, he subverts audience's thinking method because when the people think the dog will be saved, he does something the other way around. This action of antihabituation arise firstly people's surprise and breaks the "fourth's wall" which means the computer screen in a direct way of expression and achieves the effect of alienation mentioned by Brecht. In the teleplay, the classical action of knocking the desk is also a manifestation of direct interaction and supplication with audience, which belongs to an interior narrative perspective.

4) The defamiliarization of plot: The story line of The House of Cards is usually beyond audience' expectations. However, sometimes it turns out to be reasonably unexpectable. For instance, in the first season, the deceptively harmonious couple the Francis has their relationship changed in the ninth episode: Francis and Claire seems like a good couple. But in this episode, his wife Claire betrays her husband Frank for her own interests and puts him into the passive circumstance. And there is an another example, Rachel is a tool of Francis. Rachel helps Francis kill the congree man Russell. Francis orders Doug to protect Rachel in case of Rachel would tell other people that he kills the Russell. Doug is a protector and Rachel is a weak girl. But in the last episode of the second season, Doug is killed by Rachel, who has been cared by him for a long time. Because Rachel has been out of sense of safety and starts to suspect him, she does not know that Doug loves her, and that is why he protects her. The weak girl kills the man who loves her and protects her. This plot is beyond people's expectation and the defamiliarization brings the audience the surprise one after another, evoking the interest of watching.

\section{B. The Defamiliarization of Mode}

1) The defamiliarization of the transmission: The American TV show is conducted in television broadcast regularly, and the main producers are five TV networks, such as Cable News Network, Fox and so on. And the local TV stations buy the latest TV series from the top five TV networks; they broadcast it by season. The regular teleplays are aired one episode weekly, 25 episodes form just a season usually. From a broadcast season beginning in September, the teleplays broadcast on television Monday to Thursday every week, and TV shows are different every day. Since people often go to party on Friday, Thursday is the last night that people watch TV in a week. So the TV station often broadcasts TV series on Thursday.

But The House of Cards is transmitted totally differently. It is the TV series that broadcasts on the Internet. Meanwhile it presents 13 episodes at one time, which is different from the ordinary TV series. It is a way of defamiliarization of the transmission.

The House of Cards is an Internet teleplay and the mode of diffusion is different from that of the traditional telediffused TV series and also that of the Internet drama. It once broke people's viewing habit as a diffusion of 13 episodes at one time. This way of diffusion conforms better to the characteristic of continuity as a teleplay and makes the details concealed in the play become more unforgettable, which makes itself more deceivable to the audience. The Proc-era company found that nearly fifteen percent of the registered users have watched for eight hours in a single day when the second season of this teleplay became online, from which the revolutionary change brought by this defamiliarizaitional way of diffusion can be observed.

The defamiliarizaion of edition and creation: The attention is attracted by the participation of the film director and the film actors, when the main actors Kevin Spacey and Robin White are employed as directors of the second season. It turns out that this use of defamiliarization has nothing negative to this teleplay and even makes audience more curious about it.

And in the opening scene of every episode, David Fincher uses the Time-lapse to shoot the Congress, the World War II Memorial. By this way, the director shows the dirty, gritty and grungy of the American political life. The Time-lapse technology is unusual in the teleplay shooting. That is the defamiliarization in the edition and creation.

2) The defamiliarization of promotion: The influence of the big data on the cultural products should be treated rationally. Not only does it contribute some substantial information, but also it has become a trick for the publicity of the cultural products, helping the cultural products to attract the attention of the media, the audience and the agents. In terms of the issue, The House of Cards, being hotly debated, is a master of employing the trick of the big data.

Before the launching of The House of Cards, Netflix paid $\$ 200,000$ in advance to purchase the screenplay and is full of 
confidence about the screenplay. Netflix said that it found that audience who like the old British version of The House of Cards will also like the works of David Fincher, the director, and Kevin Spacey, the actor, based on the collection and analysis of countless forward, back, pause and searching behaviors of users from more than 30 million online behaviors and 4 million ratings of users subscribed by Netflix. After all these factors are comprehensively taken into consideration, the filming of the screenplay kicked off. However, lots of information showed that this was not the case. Before Netflix's purchase of The House of Cards, the producer had selected Fincher as the director and Spacey as the actor. Therefore, the filming of The House of Cards based on the analysis of the big data calls for further deliberation. However, the big data indeed played an important role in the success of The House of Cards.

The traditional promotion of teleplays is the release of posters, preview and advertorials in newspapers and Internet, the gossip is sometimes used to stir speculations. However, the way to promote The House of Cards is more concealed and efficient. By continually emphasizing the importance of the big data to The House of Cards, people who are interested in big data while not much informed about it are attracted and they turn out to be the target audience of this teleplay. After watching how the teleplay uses big data to report, the target audience are supposed to make their own conclusion by watching The House of Cards themselves and that is the excellence of its promotion. This kind of defamiliarized way of promotion enlightens those insiders indeed.

Besides, the emphasis on the importance of the big data to the filming of The House of Cards caused a sensation about the screenplay even before the filming. People paid great attention to it and had a hot discussion of it. After two days following the airing of The House of Cards, the stock price of Netflix reached a record high of forty-four point seven percent. All these effects aroused great attention of the airing platforms in various countries. Forty-four countries have purchased the airing right of the play. The hidden publicity method of the big data is attributable to the success of The House of Cards.

\section{CONCLUSION}

Proper use of defamiliarization can make the audience feel fresh about the familiar subjects. Proper defamiliarization, however, will not be far away from people's lives to make the audience feel strange. As the Swiss psychologist Edward Bullough thinks, it is better to keep an aesthetic distance from the subject in his theory of 'Psychological Distance.' Over distance or the other way around cannot bring aesthetic feelings. That is because the former will make the audience indifferent to the subject, and the latter may make the audience become utilitarian ones. So, to some extent, keeping a psychological distance can explain the function of defamiliarization.

Imagine that a person grow up in a block, which is a tourist destination. When he or she walks on the street, it may be hard for him or her to go sightseeing. For it is so familiar, all he or she has in his or her mind is where he or she can take the bus, where their office is, where the supermarket is and so on.

Thus, people can see from this that under-distance will make people take it for granted and ignore the beauty, and over-distance may not bring up the resonance, for the audience do not have this kind of experience, making it a little hard to appreciate the subject. In a word, proper psychological distance is of great importance.

Take the teleplay The House of Cards for example, it has the proper psychological distance, neither over distanced nor under distanced. As a political TV series, it undertakes some risks and has certain social influence. Thanks to the defamiliarization of the content, it is not be banned or restricted, and what is more, it wins the heart of President Obama and senior leader of China Wang Qishan.

Its proper defamiliarization is manifested by its distance from the real political life. From the character setting perspective, its hero is a white man who rises from the whip to the president. This is different from the reality that the incumbent President Obama is black, and the audience may not make a comparison between them. So, President Obama has no reason to complain about this TV series. Besides, The House of Cards is from life and more than life. The characters in the teleplay are all very competent, efficient and schemed. They can deal with all kinds of problems. However, the real life is not always like this. President Obama said: "I hope all the things can work out like The House of Cards, cruel and efficient, like Kevin Spacey, this guy fixes a lot of things." keeping a distance from the real political life will not influence the audience's political mood.

On the other hand, The House of Cards must connect with the real life, so that it can arouse the resonance among the audience. Its play writer worked as a political adviser before, so he is familiar with politics. In the teleplay, a lot of plots, scenes have something with the reality. Like the Big Peach in the teleplay. A girl died because she was sending messages while driving. This Big Peach really exists in South California. It is as high as 150 feet and has four floors. But no traffic accidents have happened like that in the TV series. Beside this, the way to inspect the Vice President candidate Francis in the teleplay has much in common with the way that President Bush chose Cheney as the Vice President. When the audience watch this teleplay, they may think of the reality by seeing these details, thus, making them eager to know what can happen next.

From this, people can see that proper defamiliarization in The House of Cards not only satisfies the audience interests, but also gains the support of the politicians, so that it can be played in lots of countries and be popular around the world.

This paper tries to analyze the defamiliarization in the teleplay The House of Cards in three aspects: the content, the mode and the promotion. It is not difficult to find the defamiliarization in the content plays a very important role in the way to success. The hit TV series The Man Who Comes from the Star and The House of Cards remind the TV producers that with the improvement of the audience 
appreciation senses, they are supposed to put the defamiliarization into use in the teleplays. Especially, the Chinese audiences need more fresh subjects than just "Little Papa," "Big Husband" and so forth. They are really in need of something new, something they never perceive before. TV producers ought to make some excellent teleplays and that is the goal they are heading to.

\section{REFERENCES}

[1] Brecht, Bertolt. 1964. Brecht on Theatre: The Development of an Aesthetic. Ed. and trans.

[2] Crawford, Lawrence. Viktor Shklovskij: Différance in Defamiliarization. Comparative

[3] Literature 36 (1984): 209-19. JSTOR. 24 February 2008.

[4] Fan Xiaodong. The House of Cards 'big data: revolution or packaging? $\begin{array}{ll}\text { Tencent } & \text { Technology }\end{array}$ http://tech.qq.com/a/20140219/014987.htm.

[5] John Willett, ed. and trans., Brecht on Theatre (New York: Hill and Wang, 1964, 91.

[6] Man San. Why is The House of Cards so hot? From: SWEEKLY NO.9,2013.

[7] Shklovsky, Viktor. "Art as Technique." Literary Theory: An Anthology. Ed. Julie Rivkin and Michael Ryan. Malden: Blackwell Publishing Ltd, 1998.

[8] Yang Yan. A New Exploration of Shklovsky's "Defamiliarization" Theory, Atrs of Russia, No.2, 2012.

[9] Zhang Jingyi. The House of Cards how far is it from politics and reality From City Night Paper 2014. 